\title{
Perceptions Of Status Consumption And The Economy
}

Jacqueline K. Eastman, Georgia Southern University, USA Kevin L. Eastman, Georgia Southern University, USA

\begin{abstract}
This paper looks at the relationship between status consumption, economic perceptions, price consciousness, brand consciousness, and value consciousness. Based on a convenience online sample of adults in the Southeast USA, most consumers are not motivated by status. There was a significant negative relationship between the level of status consumption and levels of price consciousness and value consciousness. Additionally, there was a significant negative relationship between level of status consumption and the view that it is frivolous to buy status products in an economic downturn. There was a significant positive relationship between status consumption and brand consciousness, indicating that those more motivated to consume for status are both more brand-name conscious and more likely to see a higher price as indicative of higher quality. For managers of luxury brands in this economy, the results suggest that although the status market may be smaller, status consumers are brand conscious and not price conscious. Consumers, however, may also feel that inexpensive products and discount stores can meet their status needs.
\end{abstract}

Keywords: status consumption; price consciousness; brand consciousness; value consciousness

\section{INTRODUCTION}

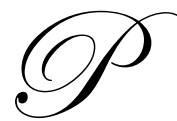

rior to the start of the current recession, research suggested that the luxury market was thriving (Han, Nunes, and Dreze, 2010; Heaney, Goldsmith, and Jusoh, 2005; Husic and Cicic, 2009; Truong, Simmons, McColl, and Kitchen, 2008). Husic and Cicic (2009, 231) found that luxury consumers behave similarly throughout the world, regardless of economic or social surroundings. This result was supported by Eastman, Fredenberger, Campbell, and Calvert (1997), who reported levels of status consumption that were comparable in America, China, and Mexico. Likewise, Eng and Bogaert (2010, 60) determined that the motivational drivers to buy luxury products are the same throughout the world (financial, functional, personal and social dimensions of luxury value perceptions) and that this global demand for luxury products is part of the global consumer culture. Consumers of luxury products come from all different social and income classes and use prestige products because it makes them feel confident and they enjoy wearing well-known brands (Husic and Cicic, 2009). Truong et al. $(2008,191)$ and Gardyn $(2002)$ noted that luxury goods have become more affordable and accessible to new customers (a phenomenon known as the "democratization of luxury"), and therefore more consumers are willing and able to pay a price premium for higher quality, higher status products. Due to this new boom in the luxury market, there is renewed interest in luxury consumption research (Truong et al., 2008).

Eng and Bogaert (2010) state there is a direct relationship between economic growth and increased spending on luxuries. Given the current state of the economy, this suggests that interest in status consumption may have changed since the start of the recession in December 2007 (Interbrand, 2008; Lahart and Dodes, 2010). Samuelson (2010) notes that the most recent recession has impacted every social class with job losses, pay cuts, and lowered home, retirement, and portfolio values, and has changed America psychologically, economically, and socially for years to come. As a result, insecurity and uncertainty have gone upscale as people plan for the worst, are reluctant to make major purchases, and potentially retard the recovery with their pessimism (Lahart and Dodes, 2010; Samuelson, 2010). Carty (2009) suggests that even ultra-wealthy consumers are tightening their belts when it comes to luxury products. 
The purpose of this paper is to examine status consumption in relation to the economy and to determine how it relates to consumer confidence, price consciousness, brand consciousness, and value consciousness. This paper is one of the first to measure status consumption since the start of the recession and to relate scores on the status consumption measure to economic concepts. Given the impact of the current economy on firms, it is becoming even more critical for managers to understand their consumers and to be able to identify differences in consumer behavior (Egol et al. 2010). More specifically, it is increasingly important to understand what consumers are looking for from luxury products and service (Gardyn 2002, 32). This paper contributes to the literature by relating consumers' level of status consumption to their level of confidence about the economy and to their levels of price, brand, and value consciousness. In addition, this paper relates status consumption to perceptions associated with buying status products on sale, at discount stores, and during downturns. From our research, suggestions for luxury marketers are offered.

\section{RELEVANT LITERATURE AND HYPOTHESES DEVELOPMENT}

Our review of the literature begins with a discussion of status consumption and how it relates to economic issues. Next, we discuss the constructs we will relate to status consumption (i.e., consumer confidence, price consciousness, brand consciousness, and value consciousness). Finally, we present our hypotheses.

\section{Status Consumption}

Status consumption is "the motivational process by which individuals strive to improve their social standing through the conspicuous consumption of consumer products that confer and symbolize status both for the individual and surrounding significant others (Kilsheimer, 1993, 341; Eastman, Goldsmith, and Flynn, 1999, 41)." It is an individual difference variable that addresses a person's motivation to consume for status. This consumptionrelated need for status is the "tendency to purchase goods and services for the status or social prestige value that they confer on their owners" regardless of income or social class level (Eastman, Goldsmith, and Flynn, 1999, 41). Status consumption is positively related to the concepts of materialism (Eastman et al., 1997; Heaney et al., 2005; Roberts, 2000) and "attention-to-social-comparison-information," or paying attention to others and what they feel and think (Heaney, et al, 2005). It is also somewhat related to compulsive buying (Roberts, 2000).

Status is derived from the evidence of wealth provided by conspicuous consumption and the power that results from the associated respect, consideration and envy of others (Veblen 1899; Eastman et al., 1999, 2). The conspicuous consumption of luxury goods provides the consumer with satisfaction from others' reactions to the wealth displayed rather than from the value of the product itself (Mason, 2001). Thus, Packard (1959, p. 5) defines status seekers as "people who are continually straining to surround themselves with visible evidence of the superior rank they are claiming."

Husic and Cicic $(2009,234)$ assert that "by using status goods as symbols, individuals communicate meaning about themselves to their reference groups." This desire for status involves consumption of items that represent status both to the individual and to surrounding significant others (Eastman et al., 1999, 43). Attitudes about luxury consumption are linked to the display of wealth and the symbolic meanings from one's social position and identity (Eng and Bogaert, 2010). Additionally, status consumption fulfils hedonic consumption needs (Eng and Bogaert, 2010). However, the literature also suggests that ultra-rich or old-money consumers prefer status goods that are not flashy and are noticeable only to others in their group, such as with the use of smaller logos (Husic and Cicic, 2009; Han, et al., 2010).

More recently in the literature, the definition of status consumption has expanded beyond the idea of conspicuous consumption (Truong et al., 2008). O'Cass and McEwen (2004) describe status consumption as the personal nature of owning status products either for internal reasons (self-reward, with no public display of the products) and/or external reasons (to signal wealth through public display). While some in the literature offer that status and conspicuousness is one and the same (Eastman et al., 1997; Eastman et al., 1999; Kilsheimer, 1993; Vigneron and Johnson, 2004), others describe status and conspicuousness as two separate but related constructs (O'Cass and McEwen, 2004; Truong et al., 2008). O'Cass and McEwen (2004, 27) define status consumption as consumers' desire to gain prestige from the acquisition of status-laden products, while conspicuous consumption is 
the overt usage of products in the presence of others. Truong et al. (2008) offer that status relates to consumers being motivated for internal reasons (self-esteem and self-respect) and/or external reasons (others' approval and envy), while conspicuousness relates to consumers being motivated by image and appearance. This study addresses status consumption as defined and measured by Eastman et al. (1997; 1999) and as utilized by Han et al. (2010), Heaney et al. (2005), Phau and Cheong (2009), Phau and Teah (2009), and Roberts (2000).

In considering how status consumption has been impacted by the economy, Interbrand (2008) found that 95 percent of consumers sampled would change their overall spending based on the current economy, and luxury items would be where they would cut their spending the most. Consumers may be bashful about buying luxury products given the current economy, the idea of the "shame of luxury" (Anonymous, 2009, 14). Egol, Clyde, Rangan, and Sanderson (2010) offer that recession-driven behaviors, such as increased savings, deferred consumption and weakened brand loyalty, are unlikely to change even as the economy improves. Thus, we propose the following four hypotheses dealing with status consumption and the current economy:

Hla: There will be a negative relationship between the level of status consumption and a consumer's reluctance to buy status products during an economic downturn.

H1b: There will be a negative relationship between the level of status consumption and a consumer's view that it is frivolous to buy status products during an economic downturn.

H1c: There will be a positive relationship between the level of status consumption and a consumer's perception that an inexpensive product cannot have status.

H1d: There will be a negative relationship between the level of status consumption and a consumer's willingness to buy status brands at a discount store.

\section{Consumer Confidence}

Consumer confidence indicators attempt to gauge consumer attitudes toward various socio-economic issues (Katona 1975). A poll conducted in May 2009 (KRC Research, 2009) found that U.S. consumers were almost evenly split on whether the economy was improving (39 percent) or the worst was yet to come (35 percent). A year later, in May 2010, the Conference Board posted its third month of gains in confidence, although consumer confidence is still very weak historically (The Conference Board, 2010). The Conference Board (2010) also found that 23.5 percent of consumers feel that general economic conditions will improve in the next six months, 20.4 percent feel that more jobs will be available in the next six months, and 11.3 percent feel that their family income will improve in the next six months. Carty (2009) offers that even those consumers who may have the money for luxury products are not buying due to eroded confidence. Thus, we propose the following hypothesis:

H2: $\quad$ There will be a positive relationship between the level of status consumption and consumer confidence in the economy in the next six months.

\section{Price Consciousness}

Yasin (2009) describes price-conscious consumers as those that follow sales campaigns and price discounts. These consumers tend to choose lower-price products and prefer to shop at sales times. The literature suggests that high price is important for status products, since: (1) status consumers are motivated to impress others, and the ability to pay a high price to consume luxury goods is a display of wealth (Eastman et al., 1999; Husic and Cicic, 2009); and (2) price is used to position a brand as a prestige product (Truong et al, 2008; Vigneron and Johnson, 2004). However, price alone is not enough to determine the desirability of a status brand (Han et al., 2010). In addition, Wakefield and Inman $(2003,207)$ suggest that "consumers are less price sensitive when making a hedonic purchase or in a social context." Thus, we propose the following hypothesis:

H3: $\quad$ There will be a negative relationship between the level of status consumption and price consciousness. 


\section{Brand Consciousness}

Yasin (2009) describes brand-conscious consumers as those who pay attention to brand names and are interested in buying well-known brand names. These consumers also see high prices as a signal of high quality. Husic and Cicic (2009) suggest that luxury consumers can come from all different social and income classes, but their identity and self-worth are determined by the visible brands they wear and the image and lifestyle projected by those brands. "Brands are seen as important in creating an identity, a sense of achievement and identification for consumers (O'Cass and McEwen, 2004, 25)." The characteristics of a product that make it a luxury brand include quality, perceived status, and brand image/recognition (Husic and Cicic, 2009; "Luxury Lowdown", 2007). However, Eng and Bogaert (2010) suggest that the idea of quality is more assumed, rather than overtly stated as a reason for purchase.

Phau and Cheong (2009) found that young status consumers may be willing to substitute sub-brands or nested brands for luxury-brand items. A subbrand uses an individual brand name next to a parent brand name to form a new composite name, while a nested brand uses a new brand name introduced by the parent brand name. Phau and Teah (2009) offer that the level of status consumption is the most significant factor for who is most likely to purchase counterfeit luxury brands (i.e., status consumers may be willing to buy counterfeits to meet their status needs).

Han, et al. (2010) introduce the concept of brand prominence (the conspicuousness of a brand's mark or logo on a product) and model status-signaling using brand prominence. They classified consumers into one of four groups based on their level of wealth and need for status: (1) patricians, or wealthy consumers who are low in need for status but want premium, quiet goods, that only those in their group can recognize; (2) parvenus, or wealthy consumers high in need for status who want loud luxury goods to signal to the less affluent that they are not one of them; (3) poseurs, who have low wealth but high status needs and use loud counterfeit status goods to emulate the wealthy; and (4) proletarians, who have both low wealth and low need for status and thus do not engage in signaling (Han et al. 2010). Thus, we propose the following hypothesis:

H4: There will be a positive relationship between level of status consumption and brand consciousness.

\section{Value Consciousness}

Lichtenstein, Netemeyer, and Burton $(1990,56)$ define value consciousness as "a concern for paying low prices, subject to some quality constraint" and as a concept that is distinct from coupon proneness. Egol et al. (2010, 2) note that "A new frugality, characterized by a strong value consciousness that dictates trade-offs in price, brand, and convenience, has become the dominant mind-set among consumers in the United States." Phau and Teah (2009) offer that there is a significant relationship between a consumers' level of value consciousness and their likelihood of buying counterfeit luxury brands, suggesting that value-conscious consumers may see counterfeit products as a better deal than the actual status brand. Thus, we propose the following hypothesis:

H5: There will be a negative relationship between status consumption and value consciousness.

\section{METHODOLOGY}

In this section we describe our sample and the measures used to test the hypotheses.

\section{Data Collection}

The nonprobability sampling technique utilized trained marketing researchers recruiting adults living in the Southeast United States to be part of an email list. This list of 732 adults was first emailed in May, 2010 to ensure that the recipients wanted to be included in the survey. Then in June, 2010, they received an email with a link to the survey on the Internet. The response rate was approximately $30 \%$ with 220 respondents. 
As shown in Table 1, the sample had a good representation of both males and females similar to that of O'Cass and McEwen (2004). The median age category was 36 to 45 years old, with relatively few elderly persons in the sample (perhaps as a result of using email as the survey method). The use of a non-elderly, adult sample to measure status was also used by Truong et al. (2008). In terms of ethnic group, the majority of the sample was white at $85.5 \%$. Approximately half the sample was married, but relatively few had children living at home. More specifically, 70.9 percent had no children under 18 living at home, 14.1 percent had one child under 18, and 13.6\% had two children under 18 living at home. The sample was highly educated, with the median having a college degree and almost 24 percent having a graduate degree (another result that may be due in part to the use of email as the survey method). Finally, all income categories were represented, with the median income between the $\$ 50,001$ to $\$ 75,000$ and $\$ 75,001$ to $\$ 100,000$ categories.

Table 1: Sample

\begin{tabular}{|c|c|}
\hline \multicolumn{2}{|l|}{ Gender } \\
\hline Male & $41.4 \%$ \\
\hline Female & $58.6 \%$ \\
\hline Age & Median: 36-45 Years Old \\
\hline $18-25$ years old & $22.3 \%$ \\
\hline $26-35$ years old & $20.5 \%$ \\
\hline $36-45$ years old & $15.9 \%$ \\
\hline $46-55$ years old & $27.7 \%$ \\
\hline $56-65$ years old & $10.0 \%$ \\
\hline Over 65 years old & $3.6 \%$ \\
\hline \multicolumn{2}{|l|}{ Ethnic } \\
\hline White & $85.5 \%$ \\
\hline African American & $8.2 \%$ \\
\hline Other & $6.3 \%$ \\
\hline \multicolumn{2}{|l|}{ Current Marital Status } \\
\hline Married & $50 \%$ \\
\hline Divorced & $14.5 \%$ \\
\hline Widowed & $.9 \%$ \\
\hline Separated & $.5 \%$ \\
\hline Never Married & \multirow{2}{*}{$\begin{array}{l}28.6 \% \\
5.5 \% \\
\end{array}$} \\
\hline A Member of an Unmarried Couple & \\
\hline How Many Children Under 18 Years Old In Household? & \begin{tabular}{|l|l|} 
Mean .46 & SD .80 \\
\end{tabular} \\
\hline Education & Median: College Graduate \\
\hline High School or Less & $8.2 \%$ \\
\hline College 1-3 years & $30.9 \%$ \\
\hline College Graduate & $37.3 \%$ \\
\hline Graduate Degree & $23.6 \%$ \\
\hline Income & Median: $\$ \mathbf{5 0 , 0 0 1 - \$ 1 0 0 , 0 0 0}$ \\
\hline Less than $\$ 25,000$ & $15.3 \%$ \\
\hline$\$ 25,001-\$ 50,000$ & $18.1 \%$ \\
\hline$\$ 50,001-\$ 75,000$ & $16.7 \%$ \\
\hline$\$ 75,001-\$ 100,000$ & $19.0 \%$ \\
\hline$\$ 100,001-\$ 150,000$ & $15.3 \%$ \\
\hline$\$ 150,001-\$ 200,000$ & $7.4 \%$ \\
\hline Over $\$ 200,000$ & $8.3 \%$ \\
\hline
\end{tabular}

\section{Measures}

Established scales were utilized to measure the various constructs (consumer confidence, price consciousness, brand quality consciousness, brand name consciousness, value consciousness, and status consumption). The scale items and related descriptive statistics are provided in Table 2.

Bechtel's (2008) three-item economic confidence measure was used to assess economic confidence. The three survey questions were measured using a scale ranging from one (worse) to three (better), with a score of two 
indicating no change. The questions addressed expected changes in the next six months with respect to general business conditions, available jobs in one's area, and total family income. We found that 28.6 percent of the sample felt that general business conditions would improve, 23.6 percent believed that more jobs would be available, and 20.9 percent expected their family incomes to improve over the six-month period. These results are similar to those reported a month earlier (May, 2010) by The Conference Board, which found that approximately one-fourth of the sample saw the economy as improving in the next six months but the majority felt the economy was going to stay basically the same over that period.

Eastman et al.'s (1999) measure was used to measure the motivation to consume for status. On average, the sample somewhat disagreed with the status items, suggesting that the majority of the sample was not motivated to consume for status. For brand consciousness, items from two sources were utilized: Donthu and Garcia (1999) and Yasin (2009). This resulted in two different aspects of brand consciousness: (1) brand-name consciousness; and (2) brand-quality consciousness. In the latter case, a higher price indicates higher quality, similar to Vigneron and Johnson's (1999) perfectionism effect. The sample was, on average, neutral about brand consciousness. Donthu and Garcia's (1999) scale was used to measure price consciousness and showed that, on average, the sample was somewhat price-conscious. Value consciousness was measured using Lichtenstein et al.'s (1990) scale and revealed that, on average, the sample was value-conscious. All the scales were unidimensional (as demonstrated with exploratory factor analysis utilizing Principal Component analysis) and reliable (with Cronbach's alpha above 0.60 which is acceptable for exploratory research per Hair, Black, Babin, Anderson, and Tatham, 2006).

The individual items used to measure economic issues impacting status were from Kilsheimer (1993). In terms of whether one is less likely to buy status products during an economic downturn, 57.2 percent of the sample agreed/strongly agreed with that statement while only $14.5 \%$ disagreed/strongly disagreed. Second, 50.9 percent agreed/strongly agreed that it is frivolous to buy status products during an economic downturn while only $15 \%$ disagreed/strongly disagreed with that belief. Third, only $2.8 \%$ of the respondents agreed/strongly agreed that inexpensive products cannot have status, while 80.9 percent disagreed/strongly disagreed with that statement. Finally, 85 percent of the sample agreed/strongly agreed that they would buy a status brand at a discount store, while only $4.1 \%$ disagreed/strongly disagreed.

\section{RESULTS}

Overall, very few consumers in the sample could be perceived as status consumers. Only fifteen percent of the sample was either neutral or agreed/strongly agreed with the status consumption construct, and only five percent had an average score on the status consumption scale above 3.5 (on a one to five scale, with a higher number indicating a higher level of status consumption). Given the low number of status consumers, a correlation matrix was utilized to measure the association between: (1) status consumption and the various economic issues; and (2) status consumption and the constructs of consumer confidence, price consciousness, brand quality consciousness, brand name consciousness, coupon proneness, and value consciousness. The results are provided in Table 3 below.

\section{Status Consumption And The Economy}

We consider first the relationship between status consumption and issues related to the economy. We found no significant relationship between a person's level of status consumption and whether that person: (1) is less likely to buy status products during an economic downturn $(\mathrm{r}=.012, \mathrm{p}=.857) ;(2)$ views inexpensive products as unable to have status $(\mathrm{r}=.084, \mathrm{p}=.212)$; or (3) would buy a status brand of a product at a discount store $(\mathrm{r}=-.077$, $\mathrm{p}=.253$ ). Thus, whether or not one is a status consumer does not impact how likely they are to buy status products during an economic downturn, whether they believe that an inexpensive product can have status, or if they would buy a status brand at a discount store (i.e., there is no support for $\mathrm{H} 1 \mathrm{a}, \mathrm{H} 1 \mathrm{c}$, or H1d). Instead, those consumers who consume for status feel basically the same as non-status consumers with respect to these issues. These results suggest that, in tough economic times, people are open to looking at different options for meeting status needs. However, there was a significant (negative) relationship between level of status consumption and the view that it would be frivolous to buy status products during an economic downturn $(r=-.302, p=.000)$. This finding supports hypothesis H1b by suggesting that those who are less likely to be status consumers are more likely to consider it frivolous to buy status products during an economic downturn. 
Table 2: Descriptive Statistics For Scales And Individual Items

\begin{tabular}{|c|c|c|c|}
\hline Topic(Item)/How Scaled/Cronbach's Alpha & Mean & SD & Source \\
\hline $\begin{array}{ll}\text { Consumer Confidence (scaled 1-3) } & .71\end{array}$ & 2.08 & .50 & \\
\hline $\begin{array}{l}\text { What do you think general business conditions will be in six months for your } \\
\text { area: }\end{array}$ & 2.17 & .61 & \\
\hline Six months from now, job availability will be: & 2.01 & .68 & \\
\hline What do you think your total family income will be in six months & 2.07 & .58 & \\
\hline Price Consciousness (scaled 1-5) $\quad .66$ & 3.59 & .64 & Donthu \& Garcia (1999) \\
\hline I usually purchase the least expensive item & 2.81 & .98 & \\
\hline I usually purchase items on sale only & 2.91 & 1.06 & \\
\hline I often find myself checking prices & 4.27 & .85 & \\
\hline A person can save a lot by shopping for bargains & 4.36 & .70 & \\
\hline Brand Quality Consciousness (scaled 1-5) $\quad .69$ & 2.67 & .86 & Yasin (2009) \\
\hline The higher the price of a product, the better the quality & 2.40 & .90 & \\
\hline I think getting better quality brands require paying higher prices & 2.94 & 1.06 & \\
\hline Brand Name Consciousness (scaled 1-5) $\quad .89$ & 3.08 & .82 & \\
\hline I usually buy brand name products & 3.32 & 1.02 & Donthu \& Garcia (1999) \\
\hline $\begin{array}{l}\text { The more known the brand of a product, the more confident I feel when } \\
\text { purchasing }\end{array}$ & 3.53 & .97 & Yasin (2009) \\
\hline $\begin{array}{l}\text { I prefer to buy best-known brands, even though they are sometimes more } \\
\text { expensive. }\end{array}$ & 2.88 & 1.00 & Yasin (2009) \\
\hline Among similar products, I tend to choose famous brands. & 3.01 & 1.03 & Yasin (2009) \\
\hline The well-known brands are best for me. & 2.68 & .93 & Yasin (2009) \\
\hline Value Consciousness Overall (scaled 1-5) & 4.12 & .55 & Lichtenstein et al. (1990) \\
\hline $\begin{array}{l}\text { I am very concerned about low prices, but I am equally concerned about product } \\
\text { quality }\end{array}$ & 4.11 & .61 & \\
\hline $\begin{array}{l}\text { When purchasing a product, I always try to maximize the quality I get for the } \\
\text { money I spend. }\end{array}$ & 4.20 & .68 & \\
\hline $\begin{array}{l}\text { I generally shop around for lower prices on products, but they still must meet } \\
\text { certain quality requirements before I will buy them. }\end{array}$ & 4.05 & .85 & \\
\hline Status Consumption Overall (scaled 1-5) & 2.30 & .74 & Eastman et al. (1999) \\
\hline I would buy a product just because it has status & 2.09 & .85 & \\
\hline I am interested in new products with status. & 2.52 & .99 & \\
\hline I would pay more for a product if it had status & 2.35 & .99 & \\
\hline The status of a product is irrelevant to me. (r) & 3.46 & 1.00 & \\
\hline $\begin{array}{l}\text { A product is more valuable to me if it has some } \\
\text { snob appeal }\end{array}$ & 2.00 & .97 & \\
\hline Individual Economic Impact and Status Items (scaled 1-5) & & & Kilsheimer (1993) \\
\hline I am less likely to buy status products during an economic downturn. & 3.52 & .96 & \\
\hline During economic downturns, it is frivolous to buy status products. & 3.49 & .96 & \\
\hline If a product is inexpensive, then it can't have status & 2.07 & .71 & \\
\hline I would buy a status brand of a product at a discount store. & 3.95 & .72 & \\
\hline
\end{tabular}

Table 3: Correlation Matrix Of Constructs

\begin{tabular}{|c|c|c|c|c|c|c|}
\hline \multicolumn{7}{|l|}{$\mathrm{n}=220$} \\
\hline Construct & 1 & 2 & 3 & 4 & 5 & 6 \\
\hline 1. Consumer Confidence & 1 & & & & & \\
\hline 2. $\quad$ Price Consciousness & -0.096 & 1 & & & & \\
\hline 3. Brand Quality Consciousness & -0.006 & -0.108 & 1 & & & \\
\hline 4. Brand Name Consciousness & $0.138 *$ & $-0.314 * *$ & $0.456 * *$ & 1 & & \\
\hline 5. Value Consumption & -0.028 & $0.463 * *$ & -0.112 & -0.112 & 1 & \\
\hline 6. Status Consumption & 0.118 & $-0.219 * *$ & $0.264 * *$ & $0.327 * *$ & -0.141 & 1 \\
\hline
\end{tabular}

*Significant at .05 level (2 tailed)

**Significant at .01 level (2 tailed) 


\section{Relationship Between Status Consumption And Constructs}

In this section, we examine the relationship between status consumption and consumer confidence, price consciousness, brand consciousness, and value consciousness. Our results suggest that: (1) there is no significant relationship between status consumption and the consumer's level of confidence in the economy over the next six months $(\mathrm{r}=.118, \mathrm{p}=.080)$; but $(2)$ there are significant relationships between status consumption and price consciousness $(\mathrm{r}=-.219, \mathrm{p}=.001)$, brand quality consciousness $(\mathrm{r}=.264, \mathrm{p}=.000)$, brand name consciousness $(\mathrm{r}=$ $.327, \mathrm{p}=.000)$, and value consciousness $(\mathrm{r}=-.141, \mathrm{p}=.037)$. Thus, we find no support for $\mathrm{H} 2$, but the results do support the remaining hypotheses $(\mathrm{H} 3, \mathrm{H} 4$, and $\mathrm{H} 4)$. Our findings suggest that consumers with greater interest in consuming for status are less price conscious and less value conscious, but more brand conscious (both in terms of a higher price indicating a higher level of brand quality and brand name consciousness. The level of status consumption though has no impact on consumer confidence of the economy.

\section{Relationship Between Status Consumption And Demographic Variables}

We also examined the correlation between status consumption and the various demographic variables used in the study, but the only significant correlation was with age $(r=-.233, p=.000)$, indicating that younger consumers are more likely to be motivated to consume for status. This is consistent with both O'Cass and McEwen (2004) and Truong et al. (2008), who utilized younger adult samples in examining status consumption. Furthermore, O'Cass and McEwen (2004) did not find a relationship between gender and status consumption. These results suggest that it is not demographic variables that can truly explain differences in status consumption, but rather other individual difference variables.

\section{DISCUSSION AND IMPLICATIONS}

\section{Status Consumption And The Economy}

Our results suggest that there are reasons for managers of luxury product brands to be concerned. First, only about 5 percent of the sample agreed that they are interested in and would buy status products. In addition, 57 percent agreed that they are less likely to buy status products during an economic downturn, and 50 percent agree that it is frivolous to do so under these economic conditions. In terms of price issues, the news gets even worse. Eighty-one percent of the sample agreed that an inexpensive product can have status, and 85 percent agreed that they would buy status brands at a discount store. Second, those respondents who consume for status felt basically the same as non-status consumers with respect to making status purchases during an economic downturn, whether or not an inexpensive product can have status, and if they would buy status products at discount stores.

Taken together, these results suggest that: (1) the majority of sampled consumers do not feel comfortable buying status or luxury products; and (2) if they are looking for status, they will consider inexpensive products and discount store merchandise to meet their need for status consumption. Additionally, the less status-conscious a consumer is, the more frivolous they would consider the purchase of status products during an economic downturn. Given the current economy, this suggests that luxury brands will be less likely to find new consumers.

\section{Relationship Between Status Consumption And Constructs}

Our finding that consumers interested in status products are brand-conscious but not price-sensitive is a positive for luxury marketers. This result is similar to Husic and Cicic's (2009) finding that luxury consumption is influenced by brand image and quality. However, there are a relatively small number of these status consumers as compared to just a few years earlier in the literature. Additionally, Hans et al. (2010) note that there may be two luxury markets, one a lower-wealth market that wants very loud prominent brand names and one a smaller, wealthier market that wants more subtle brand names and status markings.

The fact that confidence in the economy in the next six months does not impact motivation to consume for status suggests that even if the economy rebounds, the number of status consumers may not increase. Another concern for luxury marketers is that consumers may feel that inexpensive products and discount stores can meet 
their status needs. This is consistent with Egol et al.'s (2010) notion of increased frugality becoming a learned behavior.

\section{Managerial Implications}

The literature offers several suggestions for what marketers can do to reach the status market in the current economy. Carty (2010) stresses the need for innovations with luxury products, as status consumers may be more tempted to buy the newest thing. Interbrand $(2008,4)$ stresses that brands that have fostered a sense of allegiance and have developed ties with their customers are more likely to withstand the economic downturn. The key is for the brand to create and communicate differentiation in order to make the case as to why their brand is truly special, different, and offers a lasting value proposition. Egol et al. (2010) also stresses the need for better understanding different consumer segments, differentiation of marketing efforts, and engaging shoppers.

The literature also stresses the need for style, quality, and practical luxury rather than simply conspicuous consumption of status products as consumers feel the need to rationalize their purchases (Anonymous, 2009; Gardyn, 2002). We believe that this need to rationalize status purchases as not being frivolous may be even stronger in the current economy. As suggested by Phau and Cheong (2009), marketers of luxury products may want to consider the use of nested brands and subbrands as a means to reach young, status brand loyal consumers who may not be able to afford the parent status brand.

The literature also suggests that in promoting status products, marketers can suggest that: (1) other people will approve of these purchases; and (2) potential buyers make comparisons with others to gauge the success of the product in increasing the owner's status (Heaney et al., 2005). But, since materialism is a concept that is distinct from status consumption, promotions to status seekers should avoid purely materialistic appeals. Consumers want these items, not purely as material possessions, but for their status value (Heaney et al., 2005).

Gardyn (2002) suggests that luxury consumers can be segmented into three groups: (1) those who see luxury as functional and are looking for quality and enduring value; (2) those who see luxury as a reward and demonstrative of their success to others in a "smart" manner that does not leave them open to criticism; and (3) those who see luxury as an indulgence, will pay a premium for goods that express their individuality and make others take notice, and are focused on the unique emotional qualities of the luxury product. Thus, luxury marketers need to have a keen understanding of their status consumers and what they are looking for with their products.

\section{Limitations And Future Research}

One limitation of the study is that the sample was predominately white, educated, and younger. Future research, perhaps utilizing a survey method other than email, is needed to determine if the same relationships hold for a more diverse, older population. For example, Gardyn (2002) suggests that there are significant differences in luxury by ethnic group. Additionally, future research is needed to determine if these relationships exist in regions of the United States other than the Southeast. Finally, new international research on status consumption would be useful as Martin (2008) suggests that developing countries such as China, India (Eng and Bogaert, 2010), and Russia may be good markets for luxury brands.

An additional area of research would be to determine what goods and service are seen as having status and meeting status consumers' needs. Furthermore, additional variables that can impact status consumption, such as social or snob effect factors (Husic and Cicic, 2009) and the impact of reference groups on consumer perceptions of luxury (Eng and Bogaert, 2010) need to be examined. Also, additional research is needed to examine the idea of status (focusing both internally in terms of self-esteem and externally in terms of approval and envy) and conspicuousness (focusing on image and appearance to others) as two separate constructs in the current economy (Truong et al., 2008). Finally, continued research as the economy improves is needed to determine if there are changes in the level of status consumption and numbers of status consumers. 


\section{CONCLUSION}

Overall, our survey results suggest that the majority of the respondents feel that the economy will be the same in six months as it is now. They are typically neutral in terms of brand consciousness and only somewhat price conscious, but they are value conscious and most are not motivated to consume for status.

We did find significant negative relationships between level of status consumption and levels of price consciousness and value consciousness, suggesting that consumers with greater motivation to consume for status are less price- and value-conscious than other consumers. Additionally, there was a significant negative relationship between the level of status consumption and the consumer's view that it is frivolous to buy status products in an economic downturn. We found significant positive relationships between status consumption and level of brand consciousness, both in terms of brand name and the view that a higher price indicates higher quality. Thus, those who are more motivated to consume for status are both more brand-name conscious and more likely to see a higher price as indicative of higher quality. For managers, these results suggest that the status market may be smaller, but status consumers still see brand names as important. On the other hand, consumers may feel that inexpensive products and discount stores can meet their status needs.

\section{ABOUT THE AUTHORS}

Jacqueline K. Eastman (Ph.D, Florida State University) is an Associate Professor of Marketing at Georgia Southern University. She has published in journals including Journal of Academy of Marketing Science, Journal of Business Research, Journal of Business Ethics, Journal of Advertising, Journal of Marketing Theory and Practice, Journal of Consumer Marketing, and Marketing Management Journal among others.

Kevin L. Eastman (Ph.D, University of Pennsylvania) is a Professor of Finance at Georgia Southern University. He has published in journals including Journal of Risk and Insurance, Risk Management and Insurance Review, Journal of Insurance Regulation, Journal of Insurance Issues, Journal of Business Ethics, and Journal of Applied Business Research, among others.

\section{REFERENCES}

1. $\quad$ Anonymous (2009), Luxury: Bye-bye Bling, Design Week, 16 July, Vol. 24 No. 28, p. 14.

2. Bechtel, G. (2009), A Dual Source Indicator of Consumer Confidence, Sociological Methodology, Vol. 26

No. 1, pp. 299-324.

3. Carty, S.S. (2009), Even Luxury-Car Makers Struggle, USA Today, 14 January, available at www.usanowtoday.com/recession.htm.

4. Donthu, N. and Garcia, A. (1999), The Internet Shopper, Journal of Advertising Research, May/June, pp. 52-58.

5. $\quad$ Eastman, J.K., Fredenberger, B., Campbell, D., and Calvert, S. (1997), The Relationship Between Status Consumption and Materialism: A Cross-Cultural Comparison of Chinese, Mexican, and American Students, Journal of Marketing Theory and Practice, Vol. 5, pp. 52-66.

6. $\quad$ Eastman, J.K., Goldsmith, R.E., Flynn, L.R. (1999), Status Consumption in Consumer Behavior: Scale Development and Validation, Journal of Marketing Theory and Practice, Vol. 7, pp. 41-52.

7. Egol, M., Clyde, A., Rangan, K, and Sanderson, R. (2010), The New Consumer Frugality: Adapting to the Enduring Shift in U.S. Consumer Spending and Behavior, Booz \& Company, 24 February, found June 9 , 2010 at http://www.booz.com.

8. Eng, T-Y, Bogaert, J. (2010), Psychological and Cultural Insights Into Consumption of Luxury Western Brands in India, Journal of Customer Behaviour, Vol. 9 No. 1, pp. 55-75.

9. Gardyn, R. (2002), Oh, The Good Life, American Demographics, November, Vol. 24 No. 10, pp. 31-35.

10. Hair, J.F., Jr., Black, W.C., Babin, B.J., Anderson, R.E., and Tatham R.L. (2006), Multivariate Data Analysis, Pearson Prentice Hall, New Jersey.

11. Han, Y.J., Nunes, J.C., and Dreze, X. (2010), Signaling Status With Luxury Goods: The Role of Brand Prominence, Journal of Marketing, July, Vol. 74, pp. 15-30. 
12. Heaney, J-G., Goldsmith, R.E., and Jusoh, W.J.W. (2005), Status Consumption Among Malaysian

Consumers: Exploring Its Relationships with Materialism and Attention-To-Social-Comparison-

Information, Journal of International Consumer Marketing, Vol. 17 No. 4, pp. 83-98.

13. Husic, M. and Cicic, M. (2009), Luxury Consumption Factors, Journal of Fashion Marketing and Management Vol. 13 No. 2, pp. 231-245.

14. Interbrand (2008), Consumer Spending in a Recession, 1 December, found July 15, 2010 at www.interbrand.com/images/papers/33_IP_Consumer_Spending_in_a_Recession.pdf.

15. Katona, G. (1975), Psychological Economics, Elsevier, New York.

16. Kilsheimer, J.C. (1993), Status Consumption: The Development and Implications of a Scale Measuring the Motivation to Consume for Status, a dissertation submitted to the Marketing Faculty at Florida State University, FL.

17. KRC Research (2009), Majority of Americans Did Not Pay Attention to Bank Stress Tests: Vast Majority Say Results Don't Affect Views of Their Bank, New KRC Research Study Reveals, found June 4, 2009 at http://sev.prnewswire.com/banking-financial- services/20090512/DC1556912052009-1.html.

18. Lahart, J. and Dodes, R. (2010), Consumers Tighten Belts: Surprise Drop in Spending Adds to Doubt About the Recovery's Strength, Wall Street Journal, June 12-13, Vol. CCLV No. 136, pp. A1-A2.

19. Lichtenstein, D.R., Netemeyer, R.G., and Burton, S. (1990), Distinguishing Coupon Proneness From Value Consciousness: An Acquisition-Transaction Utility Theory Perspective, Journal of Marketing, July, Vol. 54, pp. 54-67.

20. (2007) Luxury Lowdown, Incentive, December, Vol. 181, pp. 10-28.

21. Martin, R. (2008), In a Recession, Go East, Marketing Magazine, 16 June, Vol. 113 No. 10, pp. 11.

22. Mason, R.S. (2001), Conspicuous Consumption: A Literature Review, European Journal of Marketing Vol. 18 No. 3, pp. 26-39.

23. O'Cass, A. and McEwen, H. (2004), Exploring Consumer Status and Conspicuous Consumption, Journal of Consumer Behaviour, Vol. 4 No. 1, pp. 25-39.

24. Packard, V. (1959), The Status Seekers, McGraw Hill, New York.

25. Phau, I. and Cheong, E. (2009), How Young Adult Consumers Evaluate Diffusion Brands: Effects of Brand Loyalty and Status Consumption, Journal of International Consumer Marketing, Vol. 21, pp. 109123.

26. Phau, I and Teah, M. (2009), Devil Wears (Counterfeit) Prada: A Study of Antecendents and Outcomes of Attitudes Towards Counterfeits of Luxury Brands, Journal of Consumer Marketing, Vol. 26 No. 1, pp. 1527.

27. Roberts, J. (2000), Consuming in a Consumer Culture: College Students, Materialism, Status Consumption, and Compulsive Buying, Marketing Management Journal, Fall/Winter, Vol. 10 No. 2, pp. 76-91.

28. Samuelson, R.J. (2010), Insecurity Goes Upscale: How the Recession Has Changed Us, Newsweek, 19 July, p. 24.

29. The Conference Board (2010), Consumer Confidence Survey Press Release, 25 May, found June 15, 2010 at www.conference-board.org/economics/consumerconfidence.cfm.

30. Truong, Y., Simmons, G., McColl, R., and Kitchen, P.J. (2008), Status and Conspicuousness - Are They Related? Strategic Marketing Implications for Luxury Brands, Journal of Strategic Marketing, July, Vol. 16 No. 3, pp. 189-203.

31. Veblen, T. (1899), The Theory of the Leisure Class, Penguin, New York.

32. Vigneron, F. and Johnson, L. (1999), A Review and Conceptual Framework of Prestige-Seeking Consumer Behavior, Academy of Marketing Science Review, available at www.amsreview.org/articles/vigneron011999.pdf.

33. Vigneron, F. and Johnson, L.W. (2004), Measuring Perceptions of Brand Luxury, Journal of Brand Management, Vol. 11 No. 6, pp. 484-506.

34. Wakefield, K.L. and Inman, J.J. (2003), Situational Price Sensitivity: The Role of Consumption Occasion, Social Context, and Income, Journal of Retailing, Vol. 79, pp. 199-212.

35. Yasin, B. (2009), The Role of Gender on Turkish Consumers' Decision-Making Styles, Advances in Consumer Research - Asia-Pacific Conference Proceedings, Vol. 8, pp. 301-308. 
NOTES 